\title{
Problems of Regional Development in Contemporary Slovak Society
}

\section{Doc. Ing. Rudolf Rybanský, CSc}

\author{
University of Ss. Cyril and Methodius in Trnava, Faculty of Mass Media Communication \\ Námestie Jozefa Herdu, 2, 91701 Trnava, Slovakia; rudolf.rybansky@ucm.sk
}

\section{PhDr. Denisa Jánošová, PhD}

University of Ss. Cyril and Methodius in Trnava, Faculty of Mass Media Communication Námestie Jozefa Herdu, 2, 91701 Trnava, Slovakia; djanosova@azet.sk

\section{Mgr. Peter Vaško}

University of Ss. Cyril and Methodius in Trnava, Faculty of Mass Media Communication Námestie Jozefa Herdu, 2, 91701 Trnava, Slovakia; petervasko.tt@gmail.com

\section{Doi:10.5901/mjss.2016.v7n1s1p327}

\begin{abstract}
The issue of regional development is among the most serious problems of contemporary Slovak society. Slovakia is characterized by significant regional differences, so this issue gets to the forefront not only in the plane of politics and the search for possible solutions, but also as a professional problem. This problem cannot be solved only by mobilizing local resources. Neither government subsidies cannot raise lagging regions to the desired level. Not many region in Slovakia, which may develop without direct foreign investment. It is the result of centrally planned economy with whom faced virtually all transition countries. These are primary reasons, for which demand for foreign direct investment (FDI) far exceeds supply. Mentioned problem was discussed in work. The objective is based on theoretical and practical knowledge recommend further development opportunities of the region, summarize all factors, that are active in the process of regional development, specifically the determining of regional marketing objectives, which can only be achieved by using marketing tools.
\end{abstract}

Keywords: region, regional development, regional disparities, regional identity, marketing tools.

\section{Introduction}

The successful growth of each national economy in today's world significantly affected by the degree of its participation in the development of the world economy. Which is this proportion larger and more diverse, so the more stable the domestic economy is. No economy cannot currently figure with no link to foreign trade, foreign economic or financial relations, or markets. This in turn has an impact on the stabilization and development of territorial parts of the country, thus regions. It is certainly in the interest of every country, to degree of development of its regions reached high level. Social and economic stability of the domestic economy in same time requires to develop different territorial units proportionally, though in them, can dominate various sectors (various forms ) of economic activity.

\section{Theoretical Framework}

The issue of regional development at the country level in the globalization process is extremely important. Regional integration overcoming national borders, the state is absorbed into transnational group, but at the same time creates a space for collective recovery some of his globalization repressed functions (Šikula, 2008). This concerns not only economic indicators. In this way we can talk about sociological and psychological influence of regionalization on residents. While the population of a particular region will not feel reflection the economic stability of the country in its neighbourhood, we can hardly talk about state social stability. We could also say that participation in positive trends of economic globalization, the population wants to feel in the immediate vicinity. The rise of the region's meaning enabled the development of a new scientific discipline, which generally we call regional science.

In the theoretical literature, it is possible to meet also with the concept of regionalization. In addition it also appears 
another new term, namely social ecology. This term is used to name new scientific procedures, which examines the involvement of a person on reshape the landscape. In several fields, which in different ways and to varying degrees touch the ground (the region) has became apparent, that citizen must participate in this projects in the region and can significantly affect their success. This includes for examples, architecture, urbanism, but also the economic development of the region. Interest in the development of the region is not entirely new. We cannot understand it as a response to the current globalization trends. Expressing spatial relationships through economical tools in some economical theories appears in the late 18th century. So in the theory of territorial development appeared term disparity. We express by him an element of diversity specific area from another territorial unit. Specifics of individual regions we can be subdivided from various perspectives - economics, geographic, social, cultural and so on. We talk about multidisciplinarity, which allows to allocate the region by a wide variety of viewpoints. From a natural point of view, may have the region other territory, than for example in terms of agricultural or industrial production. Short Dictionary of Slovak Language as codification guide defines the region as an area, county. Academic Dictionary of Foreign Words this term defines as geopolitically defined area, territory.

Also it stems from the view that the concept of regional development is very difficult to define (with regard to specific regions). In the process of globalization and European integration processes the most urgent is the impact of transnational and cross-correlation of socio - economic processes in a particular territorial unit, which works rather on the basis of historical continuity, as based on the territorial - administrative division.

The regional dimension of these processes is clearly gaining prominence, both in national and supranational sector. It shows that the identification of problems, uncovering their causes and the search for possible solutions and effective ways of solving, must be descend below the level of official administrative - administrative (municipal) units of different levels. It allows to detect on the one hand, internal differentiation problem while on the other hand, since the problem does not control administrative division, enables the identification of the boundaries of territorial definition (Faltan and Pašiak, 2004).

For regional development is important also tourism. The World Travel Organisation (WTO) defines tourism as the activities of persons travelling to and staying in places outside their usual environment for not more than one consecutive year for leisure, business and other purposes not related to the exercise of an activity remunerated from within the place visited (Goledner, Richie, 2003).

For example for regional development of Trnava region is important also religion tourism because this region is full of historical and religion monuments. Modern age and comfortable travel connections have prepared favourable conditions for a group of travellers willing to move a few thousand miles to religion actions. In the Currently, there are numerous tourist agencies all over the word, focusing on the specific destinations of pilgrimage or religious tourism (Svoboda, Šalgovičová, Polakovič, 2013).

\subsection{Legislative understanding of the term region}

In order to accurately classify the term of region it is necessary to refer to the legislative sources. The current territorial division of the Slovak Republic legally regulated by several legal rules of law:

- Act No. 221/1996 Coll. about territorial and administrative division of the Slovak Republic as amended, which provides basic division of the Slovak Republic into eight regions and 79 districts.

- Government Ordinance No. 258/1996 Coll., Issuing the list of municipalities and military districts forming individual districts, it means that the government regulation divides each cities and towns to specific districts.

- Act No. 302/2001 Coll. about self-government of higher territorial units (Act on Self-Governing Regions) as amended.

- Act No. 396/1990 Coll. on Municipalities, as amended.

- Act No. 515/2003 Coll. about the regional offices and district offices and on amendments to some legislation.

- Act No. 254/2007 about the abolition of regional offices and on amendments to Act No. 515/2003 Coll. about the regional offices and on amendments to the Act, as amended by finding the Constitutional Court of the Slovak Republic No. 263/2006.

Neither of these laws, however, specifically not define the term region, neither name synonymous definition of territory. As the basic law, we can in this direction mark Act No. 503/2001 about regional development from 18th of October 2001, which defined in Section 2 (for the purposes of the Act) region as: geographically defined area the creation and implementation of regional and structural policy at the second level or third level according to the classification of statistical territorial units. 
New rules of law cited definition considerably simplified, by Act No. 539/2008 about regional development, is the region considered: territorial unit defined by the classification of territorial units for statistics. Newly defined specification region adds a definition of the term agglomeration. Agglomeration is by this law explained as: continuous built-up urban area with peripheral zones not necessarily the urban character, which are associated with the centre.

In terms of research problems it was also important definition of the term Regional Development: Regional development is the steady growth of economic potential and social potential of the region, what increasing its economic level, performance, competitiveness and living standards of the population. Region contributes to economic development and social development (Rajčák, 2001).

Regional development can be viewed as economic and social growth potential of the region and its use for enhancing living standards of its citizens, contributing to social and economic development of the country. For this purpose it is usually developed system of support and guidance of regional development in territorial units - regions for their positive economic and social growth require special policy (Rajčák, 2001).

\subsection{Regional disparities}

Since each region is formed by certain set of elements and therefore, it may change the size and character, we need in relation to them talk about the process, so-called regionalization. Set of elements that define the region we speak regional disparities. Generally it is the sum of characters and process, which are different. The basic attributes (characteristics) of regional disparities is their occurrence, (territoriality), measurability and temporality.

According to A. Michálek (2013) the regional disparities concern:

- physical geographic potential (mineral resources, climate, position, size, localization region)

- environment (air, waste, water, biodiversity, forests, land and soil)

- transport infrastructure (road, rail and air infrastructure, water transport and transport services)

- technical infrastructure (water supply, sewerage and wastewater treatment, energy supply, information and communication technologies and tourism infrastructure)

economic disparities:

- economic performance (performance, productivity, etc.).

- economic structure (branch structure, structure by ownership)

- human potential (economic capital of the population - the skills, qualifications, work experience, mobility and business capital of the population - the rate of entrepreneurial activity, length of business activity, number of employees, turnover, profit, etc.)

social disparities:

- Population

- Health Care

- Education

- Employment and unemployment

- Social protection

- Household economy

- Crime

- Culture

The indicated number of disparities not exhaust all the factors, which may be differentiated attributes of regional disparities. The individual factors can be structured, or combined.

\subsection{Regional identity as one of the starting points of regional marketing}

Degree of citizen attachment with region (a measure of solidarity) has a major impact through its participation in regional programs. Although this fact at first glance is fairly remote issue of marketing communications, closely related. In the exercise of public administration in the region, it became quickly apparent, that for large projects - especially in the fields of environment, urban planning, architecture - citizen must get space for participation in their early stages of these programmes. Otherwise, the project will be feel the will of local government authorities. At psychological analysis of consumer behavior it is necessary to take into account regional identity, which reflects long-term relationships created by the region's population. This identity creates historical-architectural and landscape-geographical components of the environment and socio-economic characteristics of the population. Therefore, regional identity is an important factor in creating a marketing strategy of the region. For the success of business plans in the region are necessary information. 
Every marketing decision requires accurate, timely and relevant information called Marketing information system (MIS). It serves especially to analyzing and storing data from various sources. Include for example custom marketing research, agency research and so on. It can be used with other information sources - external databases, outputs statistical offices. For the marketer, it is important that the region in which he wants to operate, well-known information in terms of geography, history, population, population, infrastructure, economic potential, regional disparities and some important aspects of the influence of the region on its inhabitants. Important role in drawing up regions marketing strategies, when examining

regional disparities and research regional identity plays Slovak Archive of Social Data (SASD). In terms of marketing communication it includes secondary data that has been used

in other contexts, but can also be used for the further study of the market. When creating a communication mix we must also respond to, which parties have interest on the company marketing strategy. Every advertising campaign or other type of marketing communication follows different and specific goals, and, in particular there is a high level of dependency between the target audience and its ability to consume communicate information and decipher this information to the required extent depth. Another important factor is a type of advertising media that is employed (Zaušková, Mendelová, 2015).

It is also important to mention that the center of the marketing strategy becomes a customer strategy and therefore organizations must formulate its market supply and build relationships with customers and on a level that customers then buy products at prices that enable organizations to grow and maintain its ptofitability in the long term (Nováková, Ovsenák, 2015).

Interdependence of stakeholders is the condition for success. If we were in the previous section dealing with citizens (consumers) (which are only one interested party), then in this context it between stakeholders mention also the owners and investors, business partners, employees. In the case of regional marketing should then add to them the authorities and representatives of local governments Each of stakeholder has its own expectations. Their non-fulfillment (even partly as a compromise) a business plan can ultimately undermine. Local government authorities in this case, although considered as secondary interested party, but in fulfilling the business plans must take into account their decision-making powers and representatives relationship of local government and residents of the territory.

Regional policy in the broader sense, particularly management activities of the state, also institutions of territorial scope, which aims at creating favourable conditions for a dynamic and versatile development of the regions with the maximum use of their geographic, human and economic potential (Rajčák, 2001).

Here we met with one of the major problems concerning the creation of regional marketing strategies. This problem is the way of creating local government authorities, under which it is signed still not completely grown political culture at regional level (which, in many ways replicates, ie. high politics). In particular, the still inadequate representation of independent candidates for elected posts within the local government authorities. These candidates are in no way bound to fulfill the political programs, where also appears regional issues, but still in general form. Independent candidates also do not have to surround by people with the same political beliefs. Because that at the beginning of the new parliamentary term does not come to massive exchanges of experts in management at municipal level. At political appointees moreover, is not always decide the degree of knowledge of the issue, the decisive criterion is party membership. After taking the party's nominee to the post often leads to the defence mechanism which manifest by a lack of willingness to communicate with the public, classification of information, authoritarian leadership and so on. Paradoxically, local government authorities leading by independent candidates are often driven more technical, such as those managed by the candidate with broad party's support.

\section{Methodology}

Recently, under the influence of new technological, political and economic changes in most developed countries gradually begin to draw attention to new factors which may affect the competitiveness of regions (Rajčák, 2012).

Current challenges of regional development are based on the concept convergence, competitiveness, cohesion and stress dependence of economic development and regional dimension and the fact that the qualitative changes in social conditions are closely related to positive economic development.

To achieve the objectives it was necessary to use several methods. Collection and processing of the data for the work was carried out in the period 2014 - 2015. Analysis of the development of Trnava Region and analysis of the tools of active policy in Trnava Region was established by method of personal interviews, personal investigations face to face, and through brainstorming with experts from the field of regional development. For the realization of market research was used a personal interview with people who deal with this topic, which is the subject of the research. Respondents' 
answers were recorded in a pre-prepared questionnaire. Marketing research was created based on the answers of 100 respondents, consisting of institutions and employees in positions that have an impact on regional development.

To the questionnaire were contacted the following institutions:

- Office of Labour, Social Affairs and Family in Trnava

- Municipal Office in Trnava

- District Office in Trnava

- HTU (higher territorial unit) Trnava

\section{Research}

What is the biggest problem of the region?

At this question was given space to the view of respondents and objective assessment of the problem. From the answers was created a list of problems in the region:

- high unemployment in the region - $28 \%$ of responses

- few free job offers - $37 \%$ of responses

- low awareness of the population about events in the region - $19 \%$ of responses

- underdeveloped tourism - $16 \%$ response

Chart 1 . What is the biggest problem of the region?

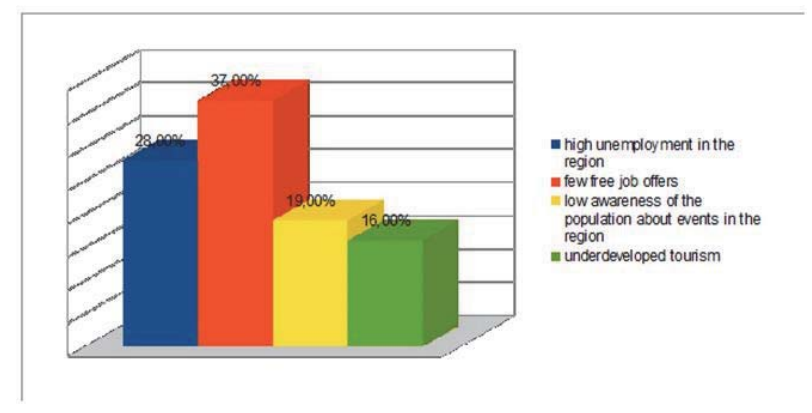

Do you think that is from side of local government authorities operating in the region exerted sufficient activity concerning the regional development?

$53 \%$ Of the respondents surveyed, tended to answer - yes agree that regional governments act sufficiently to regional development, $35 \%$ of respondents had opposite opinion and $12 \%$ of respondents to the question were unable to comment.

Chart 2. Do you think that is from side of local government authorities operating in the region exerted sufficient activity concerning the regional development?

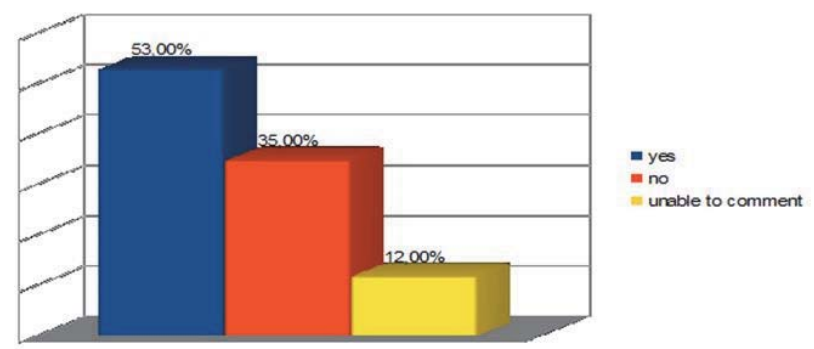

Do you think that in the region are applied all the marketing tools? 
Of the 100 respondents surveyed $49 \%$ were positive to the referred question, $21 \%$ had opposite opinion and they think that they are not used all the tools of the marketing mix of the region, which would contribute to the development and $30 \%$ to this problem were unable to comment.

Chart 3. Do you think that in the region are applied all the marketing tools?

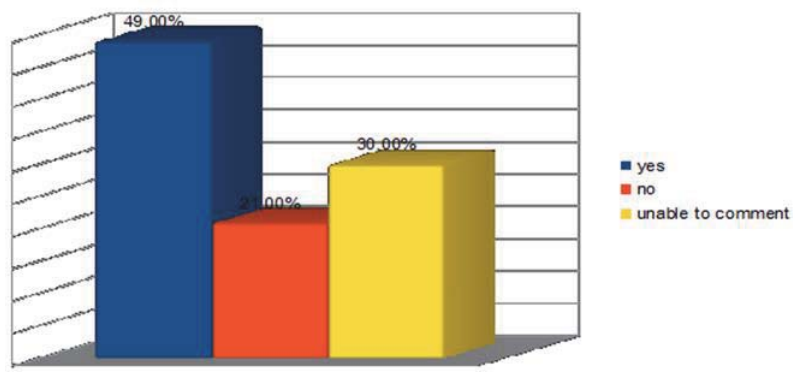

If you were to persuade tourists to visit your region, what do you attract them?

Out of 100 respondents was $41 \%$ to lure tourists to cultural monuments. $28 \%$ think that the tourist clientele attracted by sporting event, $16 \%$ believe the cultural events and 9\% think that it will be the Traditional Market in Trnava.

Chart 4. If you were to persuade tourists to visit your region, what do you attract them?

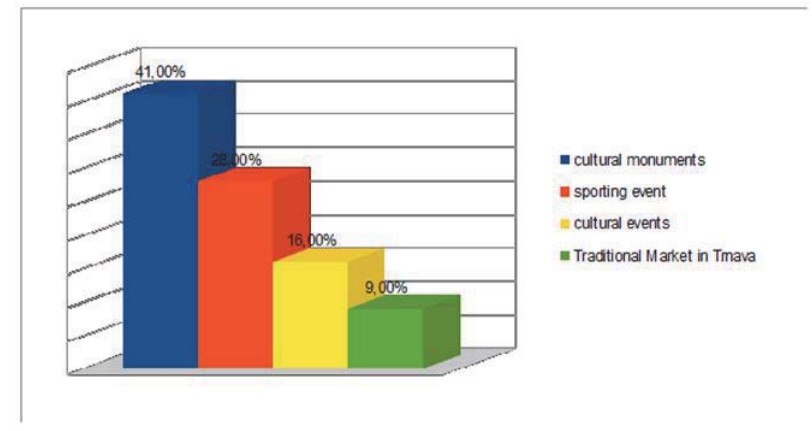

Do you have a personal goal you would like to do for the development of the region?

At this point was a great variety of answers. $22 \%$ of answers was - a greater interest in events in the region, $14 \%$ reported relaxation - leisure centre. $6 \%$ opted for bicycle paths. Other answers vary and could not be created a similar percentage group.

Chart 5. Do you have a personal goal you would like to do for the development of the region?

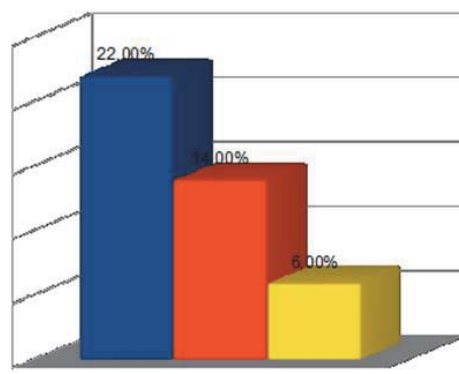

- greater interest in events in the region a relaxation - leisure centre abycle paths 


\subsection{Interpretation of research and recommendations.}

Within its own research were obtained all the information necessary for solving defined problem. The main aim was to obtain information and ideas relating to research problems. The research subject were selected institutions in Trnava Region, which directly through its activities contribute to regional development. The object of the research (final respondents) were workers in senior and middle management of these institutions. All the tools of the marketing mix of the region are in the region applied. From the observed results it can be confirmed by the active use of marketing tools. Since that $49 \%$ of respondents opted for answer yes, thus confirming knowledge that the region apply different marketing tools. $21 \%$ of respondents had the opposite opinion and relatively high percentage of respondents - $30 \%$ were unable to assess the problem.

The collected data were evaluated by computer technology and by appropriate software. The obtained data were collected in a transparent database. Part of the data evaluation was the detection of errors. That database of information was helpful in for the theory and the brings benefits for the practice. Research should examine the success of marketing communication of local government authorities in the region. Nevertheless, research has shown that local government authorities have in the marketing area a some little reserves.

Research has also suggested that the method of appointment of top management based on the recommendations of party central can create at senior and middle management a sense of social insecurity, which then affects the validity of respondents' answers, who may focus more in the answers what should respond, not on what they would like to answer. In order to keep institutional communication with the public under control, top management usually use the spokesperson or the press office. This can create a feeling that the staff at the first contact (and their management personnel) do not have information with long-term strategic importance.

In general, system of political nominees appointment to the management bodies of local governments authorities raises the meaning of question about their qualifications to perform the duties. It is complicated problem and this phenomenon therefore cannot be examined through a common questionnaire.

The relative saturation of region, FDI (foreign direct investment) can generate in the management of local governments authorities feeling, that there is no reason to seek them. To highlight the role of FDI in the region In the theoretical part we tried to also point out the negative impact in the regard of creating a dual economy. The impact of FDI to the region should therefore be considered in the long term, what the management should know.

In relation to local government authorities, it would therefore be possible to formulate a recommendation about way of communication at the level of institutions and about need to supplement marketing communication plans of the institution and their knowledge at all managerial levels of local government authorities, not only in implementation but also the theoretical part.

The obtained knowledge can be formulated conclusions in relation to the further examination of the area, thus, the conclusions of the research team. Eliminating factor "want to hear" can be achieved through a number of control issues. In the research also revealed the need to specify more precisely the problem, for example by scaling.

\section{Conclusion}

This article does not attempt to find a universally valid criteria for the earmarking of territorial units. But certainly this article wants to remind a marketing staff, that in the communication within the region have effect numerous of factors, while part of it is connected just with terminology questions of regionalization. As well as research results show marketing activities in Trnava Region are on high level. This is confirmed by the fact that the absolute majority of respondents from institutions that have a significant influence on the development of the region believe that the local government authorities spending sufficient funds for development. From this article it suggests that marketing activities especially in terms of tourism should focus on the promotion of cultural heritage, which is a significant represent in Trnava Region. Article also presents some suggestions for improving the region's attractiveness for tourists, such as build relaxation - leisure centre and bicycle paths. These proposals resulted from the research results, which were represented by respondents from key institutions and businesses in the Trnava Region. Another incentive for the creation of that text was the diversity of approaches to the specification of territorial units. However, in this regard still it needs to emphasize the fact that regional development is not just a marketing problem. To this process enters a range of other disciplines, therefore we are talking about interdisciplinary approach to region. We must realize that in addition to the socio - economic differences, are playing an increasingly more fundamental role in the cultural disparity surveyed regions.

In this article we have tried to show the need comprehensive perception of some aspects of regional marketing especially those aspects that are characteristic of the economic and social affairs. We understand that the role of the 
creative worker in marketing is to build a good marketing plan. But for its implementation which is a condition for success, effect a number of factors in these areas. When creating marketing plans is in the demarcation of the region often underestimated and also are underestimated a detailed examination of regional disparities. Although the regional government communication with the public is not a typical marketing communication, its products includes the decisions and its customers includes residents and businesses in the region. Here, too, it is therefore necessary to make a typology of consumers.

We consider it particularly interesting phenomenon called social ecology, which deals with socio-psychological phenomena in society in the context of the restricted area. It was therefore necessary that we, in this context also opened the issue of corporate communication.

At the stage of transformation of the decisive role in developing the regions includes sufficient available funds and to region bring foreign direct investment. FDI does not brings only positive, so we tried to provide more comprehensive and complex information.

The article does not have a typical marketing, economic and social character. Our intention was to provide a broader view of issues that affect regional marketing.

\section{Acknowledgements}

This article was created by the project VEGA 1/0283/15: "Aspects of marketing communication in the process of creating customer value for the B2C market in the context of maximizing market share in retail shopping gradient. "

\section{References}

Falt'an, L'., Pašiak, J. (2004). Regional Development of Slovakia. Background and current status. Bratislava: Sociological Institute of the Slovak Academy of Sciences.

Goledner, V.R., Richie, B. (2003). Tourism, Principles, Practices, Philosophies. New Jersey: Wiley \& Sons

Hasprová, M. (2007). Marketing of Towns and Municipalities. Bratislava: Ekonóm.

Michálek, A. (2013) Indicators for the identification and measurement of regional disparities (a few notes on the selection of indicators). Geographic magazine, Vol. 65, 363 - 381.

Nováková, R., Ovsenák V. (2015). Use of economic indicators for assessing the effectiveness of marketing communications. Journal of International Scientific Publications, Vol. 9, 111-117.

Ovsenák, V. (2014). Customer relationship management as an effective instrument of marketing communication. In: Quo vadis massmedia, quo vadis marketing : zborník z medzinárodnej vedeckej konferencie doktorandov (pp. 270-280). Trnava: Fakulta masmediálnej komunikácie, Univerzita sv. Cyrila a Metoda v Trnave.

Rajčák, M. (2012). Innovative milieu and clustering from the aspect of the regional development. In Forum of innovative ideas, Proceedings of the International Expert Conference organized within the framework of the project ITMS 22410420018 (pp. 155163). Trnava: University St. Cyril and Methodius.

Rajčák, M. (2001) The concept and instruments of a regional policy. Bratislava: Faculty of Architecture STU.

Svoboda, J., Šalgovičová, J., Polakovič, A. (2013). Religion and tourism in Slovakia. European Journal of Science and Theology, Vol. 9, $125-132$.

Šikula, M. (2008) Effect of qualitative changes in the institutional environment in the process of globalization on competitiveness. Working Paper, Vol. 14, 4-25.

Šikula, M. (2008). Long-term vision of the development of Slovak society. (2nd ed.). Bratislava. Economic Institute of the Slovak Academy of Sciences.

Zaušková, A., Mendelová, D., (2015). Innovation in the Slovak advertising environment. Communication Today, Vol. 6, 38-56 